\title{
Reforming the institutional and op- erational mechanism of SAARC or- ganization: Potentials of SAARC in Disaster Risk Management (DRM) in South Asia
}

Sri Lanka Journal of Social Sciences and Humanities Volume 2 Issue 1, February 2022: 97-104 ISSN: 2773 692X (Online), 27736911 (Print) Copyright: (C) 2021 The Author(s)

Published by Faculty of Social Sciences and Languages, Sabaragamuwa University of Sri Lanka Website: https://www.sab.ac.lk/sljssh DOI: http://doi.org/10.4038/sljssh.v2i1.60

\author{
Ariyawardana, S.S.N. ${ }^{1, *}$ \\ ${ }^{1}$ Department of Social Studies, Faculty of Humanities and Social Sciences, The Open University of Sri Lanka, Nawala, 11222, \\ Sri Lanka.
}

\begin{abstract}
Received: 05 May, 2021, Revised: 06 October, 2021, Accepted: 30 October, 2021.
How to Cite this Article: Ariyawardana, S.S.N. (2022). Reforming the institutional and operational mechanism of SAARC organization: Potentials of SAARC in Disaster Risk Management (DRM) in South Asia. Sri Lanka Journal of Social Sciences and Humanities, 2(1), 97104.
\end{abstract}

\begin{abstract}
SAARC is a regional agreement that was established to co-operate regional economic, political, and socio-cultural affairs in South Asia. As a highly vulnerable region towards natural and social disasters, South Asia needs a committed body that can manage sudden catastrophes in the region. Therefore, SAARC has founded SDMC and SEDMC to corporate in Disaster Risk Management (DRM) in South Asia. However, these SAARC agencies have been unsuccessful in DRM to deal with emerging disasters in the region. Hence, this study investigates the failures and weaknesses of the SAARC operational and structural framework of proceeding DRM operations while contributing to the existing body of literature regarding SAARC. The data and information of this research are based on secondary quantitative and qualitative data which were extracted from relevant printed and online materials, including organizational websites. These data and information were analyzed under five categories that are Policy Adoption Failures; Structural failures of SAARC; coordination and cooperation failures; financial inabilities in Disaster Management; Absence of Logistic Preparedness Plan; and Lack of Military Co-operation in DRM. These findings reveal that SAARC has been failed to adopt an effective and efficient DRM policy to manage emerging disasters in South Asia. Therefore, this study recommends policy reforms, restructuring the organization, establishing reliable ICT system to coordinate and co-operate DRM, introducing SAARC Disaster Management and Emergency Relief Fund in resolving financial issues, Disaster Emergency Logistic System, and SAARC Militaries Ready Group adhering ASEAN to implement an efficient DRM while reforming SAARC institutional and operational mechanism.
\end{abstract}

Keywords: DRM, Regional, SAARC, SDMC, South Asia

\section{INTRODUCTION}

The South Asian Association for Regional Co-operation (SAARC) is a commitment of seven nations in South Asia to stimulate economic, social, and cultural development within the South Asian Region (SAR) while promoting friendship and corporation with other developing countries in the world. SAARC was established on 8 December 1985 with the initial participation of seven signatories of Bangladesh, Bhutan, India, Maldives, Nepal, Pakistan, and Sri Lanka. Subsequently, Afghanistan obtained the membership of SAARC on 4 April 2007 at the $14^{\text {th }}$ SAARC summit held in New Delhi, India as the $8^{\text {th }}$ member state of the association. SAARC is a continuous effort taken to create an institutional mechanism to empower the regional integration in South Asia since the 1980 s fostering common regional identity and Inter-regional Corporation in social, economic, and cultural affairs (Ahmed and Bhatnagar, 2008).

SAARC is accountable for undertaking peace, stability, and harmony in the region following the United Nations charter while adopting non-aligned principles in sovereign equality, territorial integrity, national independence, non-use of force and non-interference in the internal affairs of other states and peaceful settlement of all disputes (SAARC Charter, 1985). The initial objectives of SAARC are to improve the living standards of the people, cultural and regional economic growth, and incorporate with other regions in world affairs. However, SAARC has adopted reforms during the last few years, realizing the importance of accelerating economic development; therefore, it declared practical economic implementation plans and policies in SAR. This recognition has pledged strong cooperation among member countries in South Asia (Shaheen, 2013). SAARC has been formed by the member states of South Asia to cooperate to find collective solutions to their common problems promoting friendship, trust, and understanding to ensure mutual respect and equity while sharing benefits. Further, SAARC has also developed an institutional framework with different levels of institutions, working groups, and member states, likewise other regional bodies of the world, to set up Regional corporations in SAR (Singh, 2009).

\footnotetext{
* Corresponding author: Tel.: +94 71777 7763; Email: s.ariyawardana@gmail.com

(iD) https://orcid.org/0000-0002-4750-6274
} 
South Asia is crowded with $1 / 5^{\text {th }}(24.89 \%)$ of the world population, which is currently estimated as 1.9 billion, reporting the highest population and density of the world. The population density in SAR is 303 per km (Worldometer, 2021). Therefore, South Asia is regularly reported natural and socio-cultural disasters on a large scale due to the rapid demographic changes, urbanization, environmental degradation, and climate changes. The landlocked location of Nepal and Bhutan is frequently faced with landslides, floods, and earthquakes as primary risks while countries such as India, Bangladesh, Sri Lanka, and the Maldives with large coastal belts are reporting cyclones and tsunamis that make severe threats to lives and occupations in SAR. Further, the "megacities" such as Mumbai, New Delhi, Dhaka, Kolkata, and Karachi are highly vulnerable to natural and social disasters, since they demonstrate a high diversification of demography and geography (White, 2015).

In this background, a dedicated organization or an institution will be essential to manage the risks of disasters in South Asia. As a major regional cooperation body, SAARC's contribution to DRM is not contented with managing emerging issues and hazards in the region. The progress and the volumes of DRM operations in South Asia conducted and initiated under SAARC have been decelerated at the present. Therefore, SAARC Comprehensive Framework on Disaster Management and Disaster Prevention in 2005 and the SAARC Disaster Management Centre (SDMC) accelerated the capacity of DRM. Hereby, SDMC has pronounced regional guidelines, technical training, and collective emergency response mechanism towards DRM. Unfortunately, the agreements on the operations of these organizational bodies are yet to be ratified by the member states in SAR. However, the SAARC efforts for implementing a regional DRM commitment have been concerned by the controversial dialogues aroused among member states. Further, this regional commitment towards DRM has been entertained by member states based on national interests other than regional interests. Unfortunately, delicate inter and intra-state political concerns within the context of South Asia are pursuing national interests towards DRM despite sustaining DRM operations in the region (White, 2015). Consequently, the SAARC efforts in DRM in emerging regional issues and crises have been unsuccessful and satisfied in South Asia.

In the present scenario, an independent and dedicated regional cooperation and a commitment should be mandatory in DRM in South Asia since the emerging issues and challenges in the region are being gradually complicated. Therefore, the active participation of SAARC is important in intervening and resolving regional issues and crises progressively emerging in society, culture, economy, and environment while promoting Regional Corporation in SAR. This review evaluates the current contribution and function of SAARC in DRM in the context of South Asia. Hereby, this study is supposed to conduct the primary investigations related to DRM operated under SAARC based on a few research questions as follows.

RQ1: What are the major vulnerabilities and threats emerging in South Asia which are recognized under SAARC Disaster Management Centre (SDMC)?

RQ2: How is the progression of current operations and failures in DRM launched by SAARC together with SDMC?

RQ3: What are reforms should be done in the mechanism of SAARC for an effective DRM to respond to emerging disasters in South Asia?
On this basis, this study examines the reasons and factors that SAARC could not form a dedicated and strong disaster management organization that could be more effective in regional DRM within the SAARC framework in South Asia.

\section{LITERATURE REVIEW}

The theoretical background of this study is based on the two parallel concepts of Disaster Risk Management (DRM) and Disaster Risk Reduction (DRR). According to Federal Ministry for Economic Cooperation and Development (2015), DRM seeks to reduce the vulnerability of the society towards extreme natural disasters and to mitigate the result of devastation in an event of such disaster through DRM. These natural hazards can generally not be prevented, but their impact can be diminished by DRM. Therefore, United Nations International Strategy for Disaster Reduction (UNISDR) defines DRM as "a systematic process of using administrative directives, organizations, and operational skills and capacities to implement strategies, policies and improved coping capacities to lessen the adverse impacts of hazards and their possibility of disaster. Disaster risk management aims to avoid, lessen or transfer the adverse effects of hazards through activities and measures for prevention, mitigation and preparedness" (UNISDR, 2009). Moreover, Disaster Risk Management (DRM) can be defined as a "concept and practice of reducing disaster risks through systematic efforts to analyses and manage the causal factors of disasters, including through reduced exposure to hazards, lessened vulnerability of people and property, wise management of land and the environment, and improved preparedness for adverse effects. Disaster reduction strategies include, primarily, vulnerability and risk assessment, as well as several institutional capacities and operational abilities." (USAID, 2011).

In addition, Disaster Risk Reduction (DRR) is a similar term used in terms of DRM. According to UNISDR (2009), DRR could be defined as a "concept and practice of reducing disaster risks through systematic efforts to analyze and manage the causal factors of disasters, including through reduced exposure to hazards, lessened vulnerability of people and property, wise management of land and the environment, and improved preparedness for adverse events" (UNISDR, 2009). As well, a comprehensive approach to reduce disaster risks is set out in the United Nations recommending Hyogo Framework for Action, adopted in 2005, with the objective of "The substantial reduction of disaster losses, in lives and the social, economic and environmental assets of communities and countries" (UNISDR, 2009).

Apart from this theoretical background, empirical evidence could be found relevant to DRR and DRM practices which are implemented by several international and regional organizations in the world at present. The United States Agency for International Development Office of U.S. Foreign Disaster Assistance (USAID/OFDA) has launched DRR programs to deal with emergency humanitarian needs while mitigating the impacts of future disasters against human survival in SAR. USAID/OFDA missions consist of hazard-resistant transitional shelters, Security Awareness Induction Training programs, humanitarian missions, providing temporary employment to rehabilitate infrastructure, building resilience against future shocks related to conflict or drought and floods, and restoring water infrastructure to reduce the risk of victimization of future water-borne disease outbreaks (USAID, 2011).

In addition, a few regional programs related to DRR in South Asia have been undertaken apart from SAARC operations. 
Incident Command System (ICS) Training for South Asia and South Asia Flash Flood Guidance System are significant regional DRR programs in this region. ICS is a management framework that is designed to incorporate people, equipment, events, amenities, and communications during an event of a disaster, enabling effective and rapid response within an organizational structure. As well, South Asia Flash Flood Guidance System which is implemented by USAID/OFDA is operated with National Meteorological and Hydrological Services (NMHSs) and national disaster management agencies along with NGOs to manage flash flood guidance and early warning systems in Afghanistan, Bangladesh, Bhutan, India, Nepal, Sri Lanka, and Pakistan (USAID, 2011). Moreover, USAID has introduced country-oriented DRR programs such as Amrao Pari Program and Strengthening Emergency Response Readiness of Emergency Working Group (EWG) in Bangladesh, ICS Training in Bhutan, CrossSectorial Strategies for Risk Reduction, Phase II in India, Nepal Earthquake Risk Management Project (NERMP II), Enhancing Community Capacity in Disaster Preparedness and Response in Nepal along with Community-based DRR Pilot Program in Pakistan (USAID, 2011).

Moreover, ASEAN has formulated a legislative working group to implement formal protocols for military groups suggesting bilateral, multilateral, or international military collaboration, training exercises, and assistance that can be useful to respond to sudden disasters (Ferris and Petz, 2013). Though there can be seen some acceptable similarities between SAARC and ASEAN regarding their strategic plans and programs for preparedness, emergency response, and technical cooperation, however, ASEAN and SAARC demonstrate considerable gaps in terms of infrastructure development, coordination, and military cooperation in DRM operations. These "treaty-based approaches are more binding approaches to cooperation, but the compliance provisions remain weak". The deep-rooted political disputes within SAARC have obstructed the progress of institutions like the SEDMC, while ASEAN is being powered by ASEAN Coordinating Center for Humanitarian Assistance on Disaster Management (AHA) in DRM operations (Lamichhane, 2016). Ferris (2014) emphasized the relevance of regional groups intervening in regional disaster management because they share people's cultures, customs, and problems. Ferris also recognized certain DRM issues at the national and regional levels, citing the fact that most DRM regulations enacted by governments do not promote the achievement of national and regional goals. She has also stressed the necessity of a regional framework in DRM, which provides a broader view of active regional organizations engaged in DRM notwithstanding individual country perspectives in an area.

This review exposes SAARC's theoretical and practical deficiencies in its role in DRM in South Asia compared to the practices of other IRGOs throughout the world. The majority of empirical studies have been based on current activities in DRR and DRM efforts by regional organizations. However, because SAARC, as the major regional organizational body, has yet to implement DRM in South Asia, research-based studies have not focused heavily on the organization's skills Table 1. Major Hazards in South Asia Region. and potential in this area. As a result, this study will look at SAARC's potential capabilities and constraints to fill in the gaps in the empirical literature and practices on DRM operations in South Asia.

\section{MATERIALS AND METHODS}

This research is originally based on secondary qualitative and quantitative data and information which are gathered through online books, journal archives, and official websites of relevant organizations, annual and monthly reports published by subjected organizations and institutions, and reading materials available on Google Scholar. Books and journal archives were used to define the theoretical framework of this study and reveal the nature of recent studies that were effective with relevant to the theme of the current research. Up to date data and information were gathered through official websites, annual and monthly reports. In this process, UN, ASEAN, SAARC, SDMC websites were followed to understand the nature of the progression of modern DRM operations at national, inter-regional, and intra-regional levels.

The data in this study is analyzed using both qualitative and quantitative methods. The qualitative analysis was used to answer the major study questions, while the quantitative analysis looked at the results quantitatively. In order to determine the key natural threats that generate the most tragedy in the region, quantitative analysis was required. Furthermore, the qualitative analysis of the study was crucial in recognizing and understanding SAARC's DRM problems and challenges, as well as proposing remedies and establishing a DRM framework and procedures for the future. Through a comparative analysis of required data and information gathered from the aforementioned organizational websites, the prospective variables regarding SAARC were identified.

The major limitations of the data collection process of this study are as follows: This study has been restricted in data and information collection since certain resource websites have not been updated. Therefore, the most recent updates that are available are used in data and information analysis. The official websites of some organizations are out of order and they are not properly operated.

\section{RESULTS AND DISCUSSION}

South Asia is recorded plenty of natural and socio-cultural disasters compared to the other regions in the world. Among them, floods, earthquakes, and droughts can be highly affected on the economy, society, and livelihoods of the people in the region (Table 1). It is reported that South Asia consists of $23 \%$ of the world population and $54 \%$ of people are dying by victimizing natural and socio-cultural disasters. Flooding of major rivers in India such as the Brahmaputra, Ganges, Indus, and Meghna destroy the Himalayan ecosystem and over 1.5 billion lives per year. The Ganges River flooding renders homeless over 600 million people who are living around. Further, glaciers' retreat of the Himalayas has become a comprehensive challenge to the region, especially in Bhutan and Nepal. Below table 1 refers to the most frequent natural hazard in SAR (Mall and Kumar, 2014).

\begin{tabular}{ll}
\hline Country & Key Hazards \\
\hline Afghanistan & Earthquake, drought, floods, landslides, extreme winter conditions, \\
& Avalanches, sand, and dust-storms, agriculture paste, Glacier retreat. \\
Bangladesh & Cyclone, floods, drought, epidemic, Glacier retreat, Sea level rise. \\
Bhutan & GLOF, flash floods, landslides, earthquake, forest fire, epidemic, Glacier retreat. \\
\hline
\end{tabular}




\begin{tabular}{ll}
\hline India & Flood, earthquake, cyclone, tsunami, epidemic, landslides, forest fire, Glacier retreat, Sea level \\
& rise. \\
Maldives & Tsunami, floods, cyclones, earthquakes, sea-level rise. \\
Nepal & Flood, landslides, earthquake, epidemic, GLOF, avalanche, fire, Glacier retreat. \\
Pakistan & Earthquake, floods, landslides, sandstorm, drought, avalanche, Glacier retreat, Sea level rise. \\
Sri Lanka & Tsunami, floods, landslide, drought, cyclone, sea-level rise. \\
\hline
\end{tabular}

Source: United Nations Environment Program and Development Alternatives, 2014.

According to the above table 1 , most countries in SAR are victimized by floods, earthquakes, cyclones, glacier retreats, and landslides. India, Bhutan, Nepal, and Pakistan show a higher volume of victimizing these natural disasters, including epidemics. According to SAARC Disaster Management Centre (SDMC), the principal natural hazards reported in SAR can be categorized as follows.

Figure 1: Principle Natural Hazards in SAARC Region

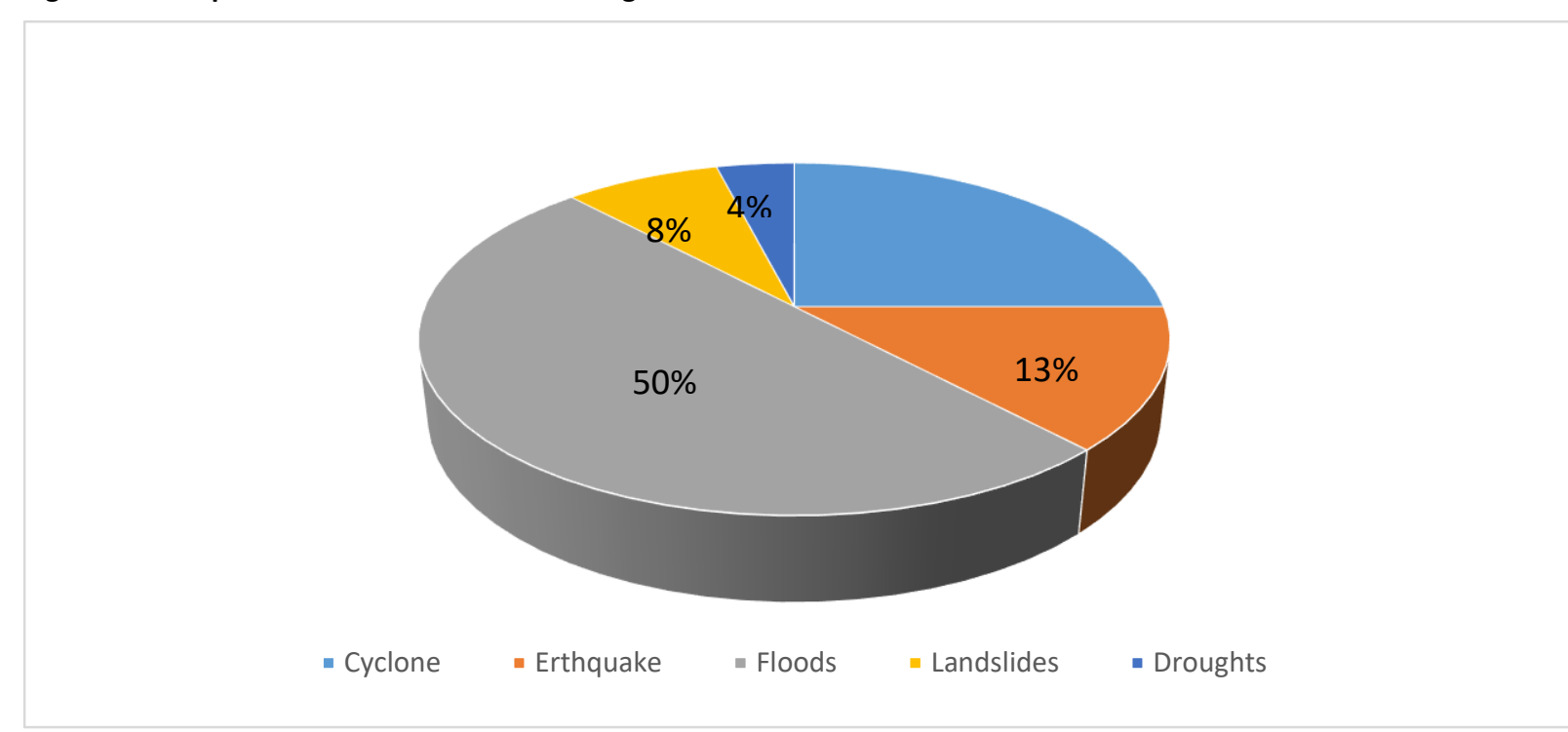

Source: United Nations Environment Program and Development Alternatives, 2014.

Figure 1 shows that $50 \%$ of deaths have been occurred due to floods while $25 \%$ of deaths are caused by cyclones. Droughts and landslides have occurred at a comparatively lower range in South Asia, while a range of pandemics is being increased as a recent trend.

In the context of SAR, social and natural hazards have gradually arisen within the region. However, the initial SAARC charter did not provide any provisions on DRM and it is covered under the general principles of the SAARC charter that are "collective self-reliance," "active collaboration," and "mutual assistance" (SAARC Charter, 1985). Therefore, SAARC Disaster Management Center (SDMC) was found in 2006 establishing country offices to respond to disasters and mitigate the risks. However, at present, SDMC is not adequate as a regional body for addressing the emerging issues through disaster management in SAR. This study found considerable weaknesses and limitations of the SAARC mechanism and operations that are causing failures in DRM in South Asia at the present. Those failures can be categorized as follows (Lamichhane, 2016):

$\checkmark$ Policy Adoption Failures

$\checkmark$ Failures of the Organizational Structure, Coordination, and Cooperation

$\checkmark$ Financing inabilities in Disaster Management

$\checkmark$ Absence of Logistic Preparedness Plan

$\checkmark$ Lack of Military Co-operation in DRM

\section{Policy Adoption Failures}

Recognition of the necessity of a strong DRM mechanism has started after the disaster of Tsunami in 2004. Therefore,
SAARC adopted SAARC Comprehensive Framework on Disaster Management associated with the Hyogo Framework for Action 2005-2015 with the new policy, guidelines, and structures for disaster management and disaster response. It prioritized policies as below:

$\checkmark$ Development and implementation of risk reduction strategies;

$\checkmark \quad$ Establishment of regional and national response mechanisms;

$\checkmark$ Establishment of regional information sharing platforms;

$\checkmark$ Development and implementation of disaster management training, education, research, and awareness programs;

$\checkmark$ Application of information and communications technology (ICT) for disaster management;

$\checkmark \quad$ Establishment of effective monitoring and evaluation mechanisms.

(Source: World Conference on Disaster Reduction, 18-22 January 2005, Kobe, Hyogo, Japan)

As a result of the policy guidelines provided by the Hyogo Framework for action 2005-2015, the SDMC was formed in 2006 to coordinate existing operations and to address the further development of DRM capabilities in South Asia. However, the expansions of DRM capacities have not successfully occurred due to the lack of agreements and policy adoptions by the organization. The major objective of establishing SDMC was to expand disaster response capacities, provide policy advice and facilitate the member states in SAR through "strategic learning, research, training, system 
development, expertise promotion and exchange of information for effective disaster risk reduction for planning and coordinating a rapid response mechanism" (Lamichhane, 2016). SDMC has given priority to the policies through its comprehensive framework, as mentioned below.

$\checkmark$ Establish and strengthen the regional disaster management system to reduce risks and to improve response and recovery management at all levels;

$\checkmark \quad$ Identify and elaborate country and regional priorities for action;

$\checkmark \quad$ Share best practices and lessons learned from disaster risk reduction efforts at national levels;

$\checkmark \quad$ Establish a regional system to develop and implement regional programs and projects for early warning;

$\checkmark \quad$ Establish a regional system of exchanging information on prevention, preparedness, and management of natural disasters;

$\checkmark$ Create a regional response mechanism dedicated to disaster preparedness, emergency relief, and rehabilitation to ensure immediate response; and

$\checkmark$ Create a regional mechanism to facilitate monitoring and evaluation of achievements towards goals and strategies.

Source: SAARC Disaster Management Centre (SDMC); SAARC Meteorological Research Centre (SMRC); South Asian Association for Regional Cooperation (SAARC), 2007.

Further, the same location of SDMC along with the head of India's National Institute of Disaster Management (NIDM) at the same premises in New Delhi, makes SDMC more reliant and dedicated as an Indian disaster management body focusing the domestic consideration rather than a regional concern. Thus, SDMC and NIDM barricade the intervention of the United States and China in DRM since they are sustaining Indian interests regarding regional programs (White, 2015). SDMC is trying to consolidate its affiliated institutions under one umbrella of SAARC Environmental and Disaster Management Centre (SEDMC) assimilating the SAARC Forestry Centre in Bhutan, the SAARC Disaster Management Centre in New Delhi, the SAARC Coastal Zone Management Centre in the Maldives, and the SAARC Meteorological Centre in Dhaka (Giri, 2014). However, SAARC has failed to identify a proper location for SEDMC to establish a coordination mechanism for all centers. Therefore, SEDMC is currently being malfunctioned in DRM in South Asia.

\section{Failures of the Organizational Structure, Coordina- tion, and Cooperation}

Coordination and corporation are very significant factors in DRM operations. According to Jensen (2012), the humanitarian aids provided by many organizations, such as nongovernmental organizations, bodies of United Nations, Military Forces barricade the coordination efforts in disasters in SAR (Jensen, 2012). Therefore, SAARC Agreement on Rapid Response for Natural Disasters (ARRND) was signed by the SAARC Member States in 2011 with the major purpose of reinforcing existing mechanisms for rapid response to disasters. The SAARC Member States are gained from legislative and administrative measures through this agreement to implement provisions "including measures for requesting and receiving assistance; conducting needs assessments; mobilizing equipment, personnel, materials, and other facilities; making regional standby arrangements containing emergency stockpiles; and ensuring quality control of relief items" (Muzaffar et al., 2017).

In the combined efforts taken by organizations and agencies to provide solutions for disasters, significant coordination failures have appeared (Pilbeam, 2013). Therefore, a single dedicated body that can grant the necessary performance in integrating several independent agencies related to DRM should be entailed for taking immediate responses and recovery actions in a sudden disaster (Paula et al., 2017). In this case, SAARC has not developed an adequate structure to grant an immediate response to a catastrophe in SAR due to its structural failures. In this manner, the SAARC Secretary-General is the authorized body for controlling and cocoordinating the activities of the SDMC procedures in DRM. However, the coordination and cooperation task between SAARC and SDMC regarding DRM is not properly undergone since the SAARC secretariat is in Kathmandu, while the SDMC is stationed in New Delhi 800 miles away from Kathmandu (Lamichhane, 2016).

Considering the EU, ASEAN, and the North American Free Trade Agreement (NAFTA), these regional organizations demonstrate a high volume of coordination and inter-dependence roles within the frame of regional cooperation in their respective regions. Therefore, people in these regions are experiencing rapid growth in their living standards and protecting their lives. Compared to South-East Asia, SAR is still maintaining a poor level of regional co-operation in DRM. Therefore, DRM is misguided and misleading due to the failure's incorporation and coordination under SAARC. As a regional organization, SAARC has remained deficient and failures in realizing the importance and objectives of DRR and DRM in South Asia in the present scenario (Upreti, \& Shashi, 2012). Therefore, SAARC should be granted proper facts and formulations, which are a much-desired step to improve the cooperation in DRM.

The main obstacles regarding SAARC cooperation can be considered as (1) rivalries between India and Pakistan and (2) Inter-state disputes that are resulting in mistrust, mutual security perceptions, and hostility in South Asia. All the SAARC members are worried that their political, economic, and territorial stability is being threatened by the neighboring countries (3) fear of Indian domination (4) instability of financial conditions of the member countries (5) asymmetry between India and other Member countries (Shaheen, 2013). Therefore, the institutional design of SAARC was not well equipped and strong enough to face complex situations of South Asia and gain through DRM.

\section{Financing inabilities in DRM}

The financing capacity of an organization is a critical factor in facing sudden disasters in any region. Therefore, the regional bodies and authorities in developing regions are forced to reform with negotiable budgets to face future disasters due to their inabilities of funding in sudden events (Yodmani, 2001). In the case of SAARC, the financial deficiencies and scarcity of resources are retarding factors in the progression of DRM programs since SAARC does not effectively pursue donors and they have not placed a dedicated financial relief fund for DRM in South Asia. Therefore, member states have to spend money on disaster relief and reconstruction. Consequently, most countries cannot mitigate sudden disasters independently due to the inabilities of selffinancing. To combat the most recent pandemic COVID-19, the Prime Minister of India suggested implementing a "COVID-19 Emergency Fund" which can be used by member 
countries to meet the financial requirements based on voluntary contributions from all the SAARC members (SAARC Disaster Management Centre, 2021). In this background, the absence of a dedicated fund in DRM will be a collective threat in SAR in a global pandemic situation, when international organizations are also facing a financial crisis during such global disasters.

\section{Absence of Logistic Preparedness Plan}

A Logistic Preparedness Plan is an important requirement in Disaster Risk Management. Poor logistic supplements may increase the threat and the risk of casualties and affected areas. The absence of a logistic preparedness plan may challenge the safety of relief workers while discouraging maintenance of logistic stock, storage system, and supply chain in sudden disasters to provide effective DRM operations in South Asia. SAARC has not still initiated any logistic preparedness plan/ logistic supply set up to promote its DRM capacities at the present. According to the "Lessons Learned for Nepal Earthquake Response" in 2015, the major logistic problems experienced in earthquake relief operation in $\mathrm{Ne}$ pal were (Landry et al., 2016):

$\checkmark \quad$ Blocking of international airport barricading the arrival of various planes with supplies and relief teams.

$\checkmark \quad$ Weaknesses of handling cargo.

$\checkmark$ Deficiency of helicopters due to interruption in inland communication.

$\checkmark$ Barriers to reaching the airport due to continuous aftershocks.

$\checkmark \quad$ Lack of stores and open spaces for shelter, rubbish, and waste.

$\checkmark$ Coordination failures of approaching supporting nations, NGOs, and groups who are willing to participate in the operation.

Source: Lessons Learned for Nepal Earthquake Response, 2015

These limitations regarding logistical preparedness and supplement had caused large setbacks in operations in DRM in South Asia. In the case of Nepal, the most limitations occurred due to the inabilities of the Nepalese National Disaster Management Organization (NDMO). However, if there was a logistic management system or mechanism in South Asia, it would be helpful to fill the gaps of Nepalese NDMO in such a sudden disaster.

\section{Lack of Civil-Military Co-operation in DRM}

According to North Atlantic Treaty Organization (NATO), Civil-military cooperation can be defined as the "coordination and cooperation, to support the mission, between the NATO Commander and civil actors, including national population and local authorities, as well as international, national, and non-governmental organizations and agencies" (North Atlantic Treaty Organization, 2003). According to NATO, a civil-military corporation should be supported by every liable authority in the region that handles the safety and security in the region. It should have proper coordination between every segment in the society including civilians. However, SAARC or SDMC has been discouraged to establish such an efficient and sufficient civil-military army that is dedicated and operated in natural and socio-cultural disasters and disputes, except for military and warrior events in the region. Lack of civil-military cooperation in SAR has become a critical issue at the present disaster management missions with the rapid growth of catastrophes in SAR. Compared with other regional organizations, SEDMC is very weak in policy formulation, consultation, coordination, and implementation of procedures to establish a civil-military corporation in SAR in disaster relief operations (Scott et al, 2009).

Though the latest policy formulation of the SAARC Agreement on the Rapid Response of Natural Disasters was signed in November 2011 by SDMC, the agreement was yet to be ratified by the member states. Therefore, supplementary agreements such as Regional Standby Agreements for Civilian and Military Assets and Coordination of Joint Disaster Relief and Emergency Response Operations are yet to be required for further negotiations to be empowered. However, the majority of the member states encourage to deploy their respective capabilities of civil and military assists emergency relief of disaster in the region with the support of global military troops. Most of the South Asian countries are currently providing support for their respective military groups in the events of disaster as a response mechanism in DRM operations (Lamichhane, 2016).

SAARC operations in DRM are challenged by the absence of dedicated civil-military relations and agencies that are being extensively deployed nationally and internationally. In the case of the Nepalese earthquake, 18 countries contributed to disaster relief operations, including India, Pakistan, Bangladesh, Sri Lanka, and Bhutan from South Asia. Despite those contributions, the Nepal army carried out their operation with the support of the Multinational Military Operations and Coordination Center (MNMCC) in co-operated with the On-Site Operations Coordination Centre (OSOCC) of the UNDAC Team (Reario, 2015). Further, the OSOCC found the Humanitarian-Military Operations Coordination Center (Hu$\mathrm{MOCC}$ ) in-corporate with Multinational Military Operations and Coordination Center (MNMCC) strengthening the borders by establishing humanitarian agencies, national and foreign militaries. However, several complaints were stimulated regarding the weak civil-military coordination in these operations due to the absence of coordination procedures between the Nepal army and the regional and international military groups (Bollettino, 2015).

On this background, a few challenges faced by SAARC in Civil-military Corporation can be introduced as (1) lack of understanding; (2) Administrative barriers; (3) lack of awareness, and (4) lack of collective working methods. Therefore, there should be a commitment entrusted by a common working procedure between civil-military cooperation at national, regional, and international levels in DRM operations. In this background, it is emphasized that SAARC needs to be granted further reforms and developments in DRM and DRR as a major regional body in South Asia.

\section{CONCLUSION AND RECOMMENDATIONS}

SAARC is a leading regional body in South Asia which is consisted of eight member states that demonstrate an active role in peace, stability, and amenity in political, economic, and socio-cultural spheres while responding to emerging issues. However, compared to the growth of social and environmental disasters, SAARC exhibits passive movements in DRM operations in South Asia. Thus, it established SAARC Disaster Management Centre (SDMC) as a dedicated agency to coordinate DRM in the region. However, the literature review of this study revealed that DRM operation in SAARC together with SDMC is not satisfactory and adequate, since the operational and structural framework of this organization is weak. Hence, this study examined the limitation and failures 
of the SAARC organization to implement effective DRM operations in South Asia. Hereby, this study resulted that South Asia is vulnerable to floods, earthquakes, cyclones, glacier retreats, landslides, and epidemics while reporting $54 \%$ disaster-related deaths. Primarily, it discovered five major failures of SAARC that this organization is not being successful in DRM in South Asia. The policy adoption failures figured out that SDMC was unsuccessful due to the lack of agreements and policies which were focused on regional determinations rather than domestic consideration. SAARC has yet to be structured and equipped in responding to emerging issues while proving failures incorporation and coordination between SAARC and SDMC owing to its incompatible lodgment in DRM operations. The absence of a dedicated financial relief fund operated under SDMC is a critical issue in rapid response to disasters in SAR. Further, this study reveals that the lack of a logistic preparedness plan is distracting the logistic supplement while setting drawbacks in DRM operations in case of rapidly responding requirements. South Asia has to depend on external organizational bodies in DRM due to the lack of civil-military cooperation adopted by SAARC. This may grant weak civil-military cooperation in DRM due to coordination failures and the absence of well-planned procedures. SAARC's civil-military cooperation was challenged by the lack of reciprocal understanding, administrative barriers, lack of awareness, and lack of collective working methods. In conclusion, SAARC, as a major regional body in South Asia is failed to adopt an effective DRM mechanism that reacts to emerging sudden threats and hazards in the region. Therefore, the institutional framework and the operational mechanism in SAARC should be reformed to grant reliable DRM procedures that can rapidly respond to emerging issues and hazards in South Asia.

\section{Recommendations}

As an initial step, the policy guidelines on Disaster Risk Management should be included in the SAARC declaration while assigning committed obligations for both SDMC and SEDMC. In parallel, SEDMC should be empowered with the ratification of all the member states as a dedicated agency that can respond to environmental disasters in the region. The development of SDMC and SEDMC will be beneficial in strengthening the institutional structure of the SAARC organization. Various training programs could be launched with the collaboration of SDMC and SEDMC concerning organizational, manpower, and resource development, coordination, supervision, and rapid response. It is important to establish formal coordination and cooperation between these two agencies that can grant mutual assistance in DRM. Relocating SDMC in the same SAARC premises along with SEDMC together will be helpful to grant an efficient and effective institutional mechanism in future SAARC operations in disaster management.

Further, it is important to develop a reliable ICT system to coordinate SAARC and its specialized agencies in DRM to gather and share data and information. SDMC and SEDMC could develop their structures with modern tools and resources to address the disasters based on their nature at the earliest with the affiliation of SAARC.

In case of co-operation and coordination matters, it will be important to expand and develop appropriate coordination procedures with regional and global organizations that can be dealt with through disaster management events. SAARC coordination and co-operation in DRM should be more focused with international organizations such as the UN, EU, ASEAN, and disaster management authorities of developed countries, which are experts in professional, technical, and logistic areas in the world.

As a solution for financial issues that have been stimulated in DRM in South Asia, it will be important to establish a "Disaster Management and Emergency Relief Fund" for SAARC which could be utilized by the SAARC Secretariat under the guidance of relevant agencies related to DRM based on the nature of the disaster. In this task, SAARC could follow the procedures of ASEAN, which could be applied in the South Asian economy. This fund could be raised by the contribution of all the member states and the partial contribution of grants from the other developed countries and organizations in the world.

Concerning logistic preparedness, SAARC can establish a Disaster Emergency Logistic Supply System similar to Disaster Emergency Logistic System for ASEAN (DELSA) (Lamichhane, 2016). This kind of system could be supported by the UN and its specialized agencies, such as United Nations Humanitarian Response Depot (UNHRD) to manage and supply logistics in DRM operations. Moreover, Mobile Logistics Hubs can be located in humanitarian staging areas and potentially other sites that are highly vulnerable to natural disasters in South Asia. These mobile hubs might be useful in rapid response to DRM.

SAARC could establish a SAARC Militaries Ready Group adhering to ASEAN with the leaderships of state defense ministers immediately to respond for disaster relief operation and humanitarian assistance on request of affected countries in the region under the supervision of SAARC (Lamichhane, 2016). In addition, SAARC can conduct military training programs with the help of the militaries of the developed countries to enhance and expand capabilities in disaster relief operations and humanitarian interventions which are necessary for DRM. SAARC should be responsible and consider all the possibilities and opportunities inside and outside the region to employ foreign civilian and military assets in the event of crises and disasters in South Asia.

\section{REFERENCES}

Ahmed, Z. S., Bhatnagar, S., (2008). SAARC and Interstate Conflicts in South Asia: Prospects and Challenges for Regionalism. Pakistan Horizon Vol. 61, No. 3 (July 2008), Pakistan Institute of International Affairs. Retrieved from https://www.jstor.org/stable/23725986 (Accessed on 11 February 2021)

BBC News, (3 May 2015). "Nepal quake: Airport Customs Holding Up Aid Relief-UN". Retrieved from https://www.bbc.com/news/world-asia32564891\#: :text=The\%20United\%20Nations\%20has\%20urged,customs $\%$ 20clearance $\%$ 20for\% 20relief\% 20supplies. (Accessed on 20 February 2021)

Bollettino, V., (2015). The Use and Coordination of Civil-Military and Defense Assets in Nepal, Liaison, Volume VII (Fall 2015), 18. Retrieved from https://www.cfe-dmha.org/Portals/O/liaison/Liaison-VII-2.pdf (Accessed on 20 February 2021)

Ferris, E.G., (2014). Better Together: Regional Capacity Building for National Disaster Risk Management. Desk review, August 06, 2014, p. 06. Retrieved from http://www.brookings.edu/ /media/research/files/papers/2014/08/06-regional-organizations-disastermanagement-ferris/better-togetherregional-capacity-building fornational-disaster-risk-managementeferris-September-2014.pdf. (Accessed on 17 February 2021)

Ferris, E. G., and Petz, D., (2013). In the Neighborhood: The Growing Role of Regional Organizations in Disaster Risk Management. Brookings Institution, London School of Economics. Project on Internal Displacement. 2013. Retrieved from http://pacificdisaster.net/pdnadmin/data/original/Brookings_2013_neighbourhood pdf. (Accessed on 16 February 2021) 
Giri. A., (2014). "SAARC to trim Regional centers "Kathmandu Post, Nov 23, 2014. Retrieved from https://kathmandupost.com/miscellaneous/2014\%E2\%80\%9311\%E2\%80\%9323/saarc-to-trim-regional-centres (Accessed on 18 February 2021)

Jensen, L., M., (2012). Humanitarian cluster leads: Lessons from 4PLs. Journal of Humanitarian Logistics and Supply Chain Management, 2(2), pp. 148-160.

Lamichhane, S., (2016). Enhancing SAARC disaster management: a comparative study with ASEAN coordinating center for humanitarian assistance on disaster management. Thesis and Dissertations (2016 March). Calhoun, Institutional Archive of the Novel Post Graduate School. Retrieved from https://core.ac.uk/download/pdf/36740616.pdf (Accessed on 16 February 2021)

Landry, M., D., Sheppard, P., S., Leung, K., Retis, C., Salvador, E., C., Raman, S., R., (2016). The 2015 Nepal Earthquake(s): Lessons Learned From the Disability and Rehabilitation Sector's Preparation for, and Response to, Natural Disasters. Physical Therapy, Volume 96, Issue 11, 1 November 2016, Pages 1714-1723. Retrieved from https://doi.org/10.2522/ptj.20150677 (Accessed on 20 February 2021)

Lessons Learned for Nepal Earthquake Response, (2015) ACAPS, April 27 2015. Retrieved from http://acaps.org/img/documents/l-acaps_lessons_learned_nepal_earthquake_27_april_2015.pdf. (Accessed on 20 February 2021)

Mall, R., K., Kumar, S., (2014). Integration of Disaster Risk Reduction and Climate Change Adaptation in SAARC Region. Banaras Hindu University, SAARC Disaster Management Centre: ISBN 818530563-3. Retrieved from https://www.researchgate.net/publication/299430726_Integration_of_Disaster_Risk_Reduction_and_Climate Change Adaptation in SAARC Region (Accessed on 19 February 2021)

MBZ, (2012). Strategy Paper 6/2012- Cross-sectoral Strategy on Poverty Reduction. Federal Ministry for Economic Cooperation and Development, Berlin Bonn, 2010. Retrieved from https://www.bmz.de/en/publications/type_of_publication/strategies/Strategiepapier323_04_2012.pdf (Accessed on 15 February 2021)

Metcalfe, V., Haysom, S., and Gordon, S., (2012) "Trends and Challenges in Humanitarian Civil-Military Coordination: A Review of the Literature," London: The Humanitarian Policy Group (2012), 17. Retrieved from https://www.odi.org/sites/odi.org.uk/files/odi-assets/publications-opinion-files/7679.pdf (Accessed on 20 February 2021)

Muzaffar, M., Jathol, I., Yaseen, Z., (2017). SAARC: An Evaluation of its Achievements, Failures, and Compulsion for cooperation. Global Political Review (GPR), Vol. II No. 1 (2017). Pp. 36-45. Retrieved from https://www.gprjournal.com/jadmin/Auther/31rvl-

olA2LALouq9hkR/BXOBIUWk6n.pdf. (Accessed on 19 February 2021)

North Atlantic Treaty Organization, (2003). AJP-9 NATO Civil-Military Cooperation (CIMIC) Doctrine (June 2003). Retrieved from https://www.nato.int/ims/docu/ajp-9.pdf. (Accessed on 20 February 2021)

Paula, A., D., Leiras A., Lukosevicius, A., Dei (2017). Organizational Structure for Disaster Management Projects. Disaster Management and Human Health Risk V. WIT Transactions on The Built Environment, Vo 173, WIT Press. Pp 33-42. Retrieved from https://www.witpress.com/Secure/elibrary/papers/DMAN17/DMAN17004FU1.pdf (Accessed on 18 February 2021)

Pilbeam, C., (2013). Coordinating temporary organizations in international development through social and temporal embeddedness. International Journal of Project Management, 31(2), pp. 190-199.

Qadri, H.M. (2008). SAARC and globalization: issues, Prospects \& Policy Prescriptions. Lahore, Minhaj ul Quran publications. Pp 30-34

Reario, R., (2015). THE HuM OCC Typhoon Haiyan, Cyclone Pam, and Nepal Earthquake, Liaison, Volume VII (Fall 2015), 11. Retrieved from https://www.cfe-dmha.org/Portals/0/liaison/Liaison-VII-2.pdf. (Accessed on 20 February 2021)

SAARC, (1985). SAARC Charter. Retrieved from http://www.saarc sec.org/SAARC-Charter/5/ (Accessed on 17 February 2021)

SAARC. (2005). SAARC Comprehensive Framework on Disaster Management. Retrieved from http://saarcsdmc.nic.in/pdf/framework.pdf. (Accessed on 18 February 2021)

Scott, R., R., Maclay, J., D., and Sokolow, D., (2009). NATO and Allied CivilMilitary Cooperation Doctrine, Operations, \& Organization of Forces, NATO and Allied Civil Affairs, Center for Strategic and International
Studies (CSIS). Retrieved from https://csis-website-prod.s3.amazonaws.com/s3fspublic/legacy_files/files/me-

dia/csis/pubs/090128 nato civil military doctrine and ops.pdf (Accessed on 20 February 2021)

Shaheen, I., (2013). South Asian Association for Regional Cooperation (SAARC): Its Role, Hurdles, and Prospects. IOSR Journal of Humanities and Social Science (IOSR-JHSS) Volume 15, Issue 6 (Sep. - Oct. 2013), pp. 01-09. Retrieved from http://www.iosrjournals.org/iosr-jhss/papers/Vol15-issue6/A01560109.pdf?id=7363 (Accessed on 14 February 2021)

Singh, R., (2009). Relevance of SAARC in South Asian Context. The Indian Journal of Political Science, Vol. 70, No. 1 (JAN. - MAR., 2009), Indian Political Science Association. pp. 239-248. Retrieved from https://www.jstor.org/stable/41856511?seq=1 (Accessed on 14 February 2021)

UNISDR (United Nations International Strategy for Disaster Reduction). 2009. UNISDR terminology on disaster risk reduction. Geneva: UNISDR. P. 30. Retrieved from http://www.preventionweb.net/files/7817_UNISDRTerminologyEnglish.pdf (Accessed on 19 February 2021)

UNISDR (United States Agency for International Development). 2011. Introduction To Disaster Risk Reduction. P. 13. Retrieved from https://www.preventionweb.net/files/26081_kp1concepdisasterrisk1.pdf (Accessed on 19 April 2021)

United Nations Environment Program and Development Alternatives (2014). South Asia Environment Outlook 2014: UNEP, SAARC, and DA. http://www.sacep.org/pdf/Reports-Technical/2014-South-Asia-Environment-Outlook-2014.pdf

Upreti, B.C. \& Upaydhyay, S. (2012). Emerging Challenges of Security in South Asia: nature, dimensions \& implications. South Asian studies series (the University of Rajasthan. South Asia Studies Centre), Vol. 46. New Delhi: Kalinga Publications. Retrieved from https://books.google.lk/books?id=x65eMwEACAAJ (Accessed on 19 February 2021)

USAID. (2011). Disaster Risk Reduction (DRR) - South Asia. Fact Sheet \#1, Fiscal Year (Fy) 2011. Retrieved from https://reliefweb.int/sites/reliefweb.int/files/resources/Full_Report_3153.pdf (Accessed on 15 February 2021)

White, S., (2015). A Critical Disconnect: The Role of SAARC in Building the DRM Capacities of South Asian Countries. Brookings-LSE, Project on internal displacement, 1775 Massachusetts Ave, NW Washington, DC 20036, USA. Retrieved from https://www.brookings.edu/wp-content/uploads/2016/06/Role-of-SAARC-in-DRM-South-Asia-May-52015.pdf (Accessed on 14 February 2021)

World Conference on Disaster Reduction, (18-22 January 2005). Hyogo Framework for Action 2005-2015: Building the Resilience of Nations and Communities to Disasters. Final report of the World Conference on Disaster Reduction (A/CONF.206/6), Kobe, Hyogo, Japan. Retrieved from https://www.unisdr.org/2005/wcdr/intergover/officialdoc/L-docs/Hyogo-framework-for-action-english.pdf (Accessed on 14 February 2021)

Worldometer, (2021). Elaboration of data by United Nations, Department of Economic and Social Affairs, Population Division. World Population Prospects: The 2019 Revision. Retrieved from https://www.worldometers.info/world-population/southern-asiapopulation/ (Accessed on 14 February 2021)

Yodmani, S., (2001) Disaster Risk Management and Vulnerability Reduction: Protecting the Poor, The Center, p. 02. Retrieved from http://drr.upeace.org/english/documents/References/Topic\%205Risk\%20Management\%20and\%20Adaptation\%20to\%20Climate\%20Change/Yodmani\%202000\%20Disast er\%20Risk\%20Management.pdf (Accessed on 19 February 2021) 